\title{
EVALUATING AND GOMPARING THE PROCESS OF DEVELOPMENT IN EGYPT AND TURKEY
}

\author{
Yrd. Doç. Or. Kemal Baş \\ Mersin Üniversitesi \\ iktisadi ve İdari Bilimler Fakültesi
}

\section{Musir ve Türkiye'de Kalkınma Sürecinin Karşllkl Olarak Değerlendirilmesi \\ Özet}

Bu çalışmada Mısır ve Türkiyènin kalkınma sureçleri karşılaşınlarak değeriendirilmekiedir. Birleşmiş Milletlerin Insani Gelışme Endeksi dahil olmak üzere, kalkınmanın çeşitli boyutları göz onunde bulunduroılmuştur. Bu unsurlar: doğuşla yaşam beklentisi, yetişkin okur-yazarlığı. gelir ve yoksulluk, gelir dağılımındaki eşitsizlik ıle coneğin ve toprağın verimliliğidir. Bu unsurlar 1960 'l yıllardan itibaren günümüze kadar değertendırihmiş ve iki ialkenin ne oranda başanıl oldukları karşılaşırılarak belirtilmiştir. Yakın geçmişteki tecrïbe, Türkıye'nin doğgşta yaşam beklentisi ve yetişkin okur-yazarlı̆̆ı hususunda Mısır"a göre daha başarılı olduğunt göstermekıcdir. Yoksulluğun çeşitli ölçunileri. bu konuda iki ülkenin de aşağ jukarı aynı konumda olduklarm gostermektedir. Ancak, uluslararası karşılaştırınalat. Mısır'da yoksulluğun 'Türkiye’dekinden daha fazla olduğunu göstermektedir. 'Türkive'de gelir dağılımındaki eşitsizliğın Mısır'dakine gore daha fazla ulduğu görümektedir. Ioprak verimliliğg hususunda. yakın geçmişte yapılan

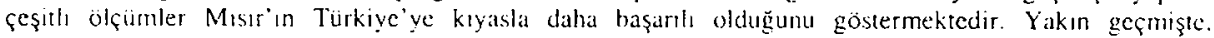
endustride emeğgn verimliliğinin de Misır'da Türkive'ye göre daha yüksck olduğu görülmektedir.

Anahtar Kelimeler: Kalkınma süreci, yoksulluk, yaşam beklentisı, okur-yazarlık, ürełkenlik.

\begin{abstract}
This article evaluates and compares the process of development in Egypt and Turkey. Various dimensions of development are considered including the ones declared by the Human Development Index of the United Nations. These dimensions are life expectancy at birth, adult literacy, income and poverty, inequality in income distribution and producuvity of labor and land. The achievements of the two countries, Egypt and Turkey, in cach of these dimensions are evaluated since the 1960 s to the present and compared to each other. The recent experience indicales that Turkey performed better than Egypt in terms of life expectancy at birth and adult literacy. The various measures of poveny indicated that the level of poverty is about the same in the two countries. However, the incernational comparison indicated a higher level of poverty in Egypt than in Turkey. Incone distribution is more unequal in Tutkey than in Fgypt. Various measures of produccivity of land indicated higher levels are achieved recently in Egypt than in Turkey. Recent labor productivity in industry was also higher in Fgypt than in Turkcy.
\end{abstract}

Keywords: Development process, poverty, life expectancy, literacy, productivity. 
- Ankara Üniversitesi SBF Dergisi • 59-4

\section{Evaluating and Comparing the Process of Development in Egypt and Turkey}

\section{Introduction}

The concept of "Development" has different meanings in different economic, social and cultural conditions. People of developing countries associate this term with a rise in income whereas the people of developed countries consider it as a rise in general standards of living. Therefore, the concept of development is rather difficult to define. In general terms it may mean being able to reach a high level of economic, social and cultural values. Many economists assume that development of a country involves not only increasing incomes but also improving health and nutrition of the population, improving access to education, increasing quality of resources, improving the equality in distribution of resources, reducing poverty, and improving human rights. The United Nations Development Program developed the concept of Human Development Index (HDI). According to the HDI, "Human development is a process of enlarging people's choices. In principle, these choices can be infinite and change over time. But, at all levels of development, the threc essential ones are for people to lead a long and healthy life, to acquire knowledge and to have access to resources needed for a decent standard of living."

In a recent study Adams (2000) compares Egypt's developmental record with that of forty other developing countries. He uses the thrce dimensions of development declared by the HDI, as in the above quotation. He further includes a measure of the degree of inequality in access to resources and productivity of land and labor. The dimensions of development that are considered in this article are the same as the ones in Adams' article. Many developing countries including Egypt and Turkey report measurable data on all dimensions of the development considered. 
This article assesses and compares the development process in Egypt and Turkey. The various dimensions of development that are considered include life expectancy at birth, adult literacy, income and poverty, inequality in income distribution and productivity of labor and land. The achievements of the two countries Egypt and Turkey, in each of these dimensions are evaluated since the 1960 s to the present and compared to each other. The comparison of the development process in Egypt and Turkey led to mixed results. The experiences in the late 1990s indicate that the life expectancy at birth and adult literacy rates are higher in Turkey than in Egypt. Various measures of poverty indicated that the level of poverty is about the same in the two countries. However, the international comparison indicated a higher level of poverty in Egypt than in Turkey. Income distribution is more unequal in Turkey than in Egypt. Recently, higher levels of land productivity were achieved in Egypt than in Turkey by various measures. Recent labor productivity was also higher in Egypt than in Turkey.

This paper proceeds as follows. Sections 2 and 3 evaluate and compare the recent development records of Egypt and Turkey in terms of life expectancy at birth and adult literacy rates respectively. Section 4 examines the developments in poverty in the two countries. Section 5 evaluates the income distribution in Egypt and Turkey. Section 6 concentrates on land and labor productivity in the two countries. Finally, a summary and conclusions appear in section 7 .

\section{Life Expectancy}

In the Human Development Report, life expectancy at birth is defined as "the number of years a newborn infant would live if prevailing patterns of mortality at the time birth were to stay the same throughout the child's life" (United Nations Development Program, 1998:219). Life expectancy at birth is a measure of longevity. It is an outcome of the improvements in the health system and fertility levels in the country. Its major shortcoming is that it is a quantitative measure with no indication about the quality of life that is lived.

Table 1 gives the life expectancy at birth in Egypt and Turkey during 1960-1997. Life expectancy at birth improved significantly in both Egypt and Turkey. It increased from a low of

46 years in 1960 to 68 in 2001 in Egypt. It increased from 51 in 1960 to 70 in 2001 in Turkey. During this period Egypt's average rate of improvement in life expectancy exceeded that of Turkey although in 2001 Turkey's life expectancy at birth is significantly higher than that of Egypt. 
Table 1: Life expectancy at birth, 1960 - 2001: Egypt versus Turkey

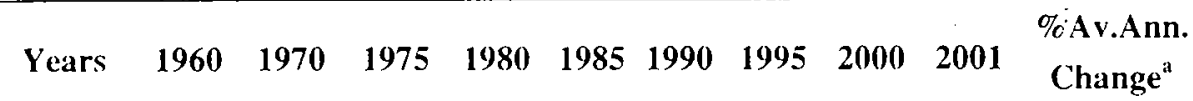

\section{Egypt}

$\begin{array}{lcccccccccc}\text { Fomale } & \text { n.d. } & 52 & 55 & 57 & 61 & 64 & 67 & 69 & 70 & 1.12 \\ \text { Male } & \text { n.a. } & 50 & 52 & 54 & 58 & 61 & 64 & 66 & 67 & 1.09 \\ \text { Total } & 46 & 51 & 53 & 56 & 59 & 63 & 65 & 68 & 68 & 1.16\end{array}$

\section{Turkey}

$\begin{array}{lcccccccccc}\text { Female } & \text { n.a. } & 59 & 62 & 64 & 66 & 68 & 71 & 72 & 72 & 0.71 \\ \text { Male } & \text { n.a. } & 55 & 57 & 59 & 61 & 64 & 66 & 67 & 67 & 0.70 \\ \text { Total } & 51 & 57 & 59 & 61 & 63 & 66 & 68 & 70 & 70 & 0.91\end{array}$

a Average annual rates of change are weighted by population.

Source: World Bank, 2002.

In most developing countries such as Egypt and Turkey the trends and differentials in life expectancy at birth are mainly influenced by the trends and differentials in infant ${ }^{1}$ and child ${ }^{2}$ mortality rates (United Nations Development Program, 1990:19). One of the reasons behind this improvement in life expectancy at birth is the dramatic decline in child mortality rates both in Egypt and Turkey. The mortality rate in Egypt for children younger than five years declined from 2.35 in 1970 to 41 in 2001 (World Bank, 2002). The mortality rate in Turkey for children younger than five years declined from 201 in 1970 to 43 in 2001 (World Bank, 2002). The second reason is the significant increase in the supply of doctors in the both countries. The public health expenditure as percent of Gross Domestic Product (GDP) in Egypt was 1.6 in 1995 and increased to 1.8 in 2000. The same percentages in Turkey were 2.4 in 1995 and increased to 3.5 in 2000. During this period the Egyptian government has done much to increase the numbers of public health clinics and to improve the public access to safe water and sanitation facilities. Similarly, in Turkey health conditions especially those surrounding pregnancy and birth in urban as well as rural areas improved significantly. The Ministry of Health established

1 Infant mortality rate is the number of infants who die before reaching one year of age expressed per one thousand live births in a given year.

2 Child mortality rate refers to the annual number of deaths in the age group 1-4 years per one thousand live births in a given year. 
the General Directorate of Mother and Child Health and Family Planning in 1965. This has contributed to the significant declines in infant and child mortality. A number of other factors have been important for the drop in the infant mortality rates. These factors included the increases in the level of incomes (World Bank, 1998-1999:17) and the improvements in the education of women. Subbarao and Raney (1995) found that the secondary level of schooling of women when interacted with family-planning programs significantly reduces the fertility and infant mortality rates. The significant improvements in the level of incomes and the schooling of women both in Egypt and Turkey contributed to reducing fertility and infant mortality rates and thereby increasing the life expectancy at birth.

\section{Adult Literacy}

Adult literacy rate of a country is another widely used indicator of development. Although it has some limitations it is closely related to development through its effect on the productivity of land, labor and capital. There is international evidence that more and better educated people can use resources effectively and therefore have higher levels of productivity than the uneducated ones, survey cvidence from group of low income countries indicate that average education of four years of primary schooling enhances farm output by 8.7 percent (HADDAD, 1990). Further, education significantly influences choice of crops and utilization of modern production techniques and inputs as well as non-farm activities such as utilization of credit (TILAK, 1989:24).

Adult literacy is measured by "the percentage of people aged 15 and above who can, with understanding, both read and write a short, simple statement on their daily life" (United Nations Development Program, 1998: 219). Table 2 shows the adult literacy rates in Egypt and Turkey in 1960 and 2000. The adult literacy rates were rather low in both Egypt and Turkey in 1960. There were significant improvements over time in both countries. However, in 2000, Turkey's adult literacy rate was about 85 percent while that of Egypt was only about 55 percent. Over this period the rate of improvement has been much faster in Turkey than in Egypt: 3.10 percent versus 2.24 percent respectively. To achieve literacy may require more effort in Egypt than in Turkey. In Egypt the written and spoken languages are different whereas in Turkey they are the same. Therefore, it takes longer for a person to be literate in the written language in Egypt than in Turkey. 
Ankara Universitesi SBF Dergisi • 59-4

Table 2: Adult literacy, $1960-2000$, Egypt and Turkey

Literacy Rate \%Av. Ann. Change

\begin{tabular}{lcccccc} 
Years & 1960 & 1970 & 1980 & 1990 & 2000 & $1960-2000$ \\
Egypt & .29 & 43 & 44 & 47 & 55 & 2.24 \\
Turkey & 38 & 50 & 65.6 & 75 & 85 & 3.10 \\
\hline
\end{tabular}

Source: UNDP Human Development, various years.

Literacy, especially femalc literacy is a problem both in Egypt and in Turkey. Both countries share an Islamic tradition. Islamic tradition has not been favorable for the education of girls. In particular in the rural areas conservative families are reluctant to send girls to the same schools as with boys. In 1998 the female literacy rates are only 42 percent in Egypt and 75 percent in Turkey (Tansel, 2002: 23). Further in the rural areas the drop-out rates are higher than in the urban areas in both Egypt and Turkey. In the rural areas parents do not want to loose time by educating their children. Therefore children leave school to work on the family farm or business.

I.iteracy, especially female literacy, is significantly higher in Turkey than in Egypt. The single, most important factor behind this difference is that primary level of schooling has been compulsory for both boys and girls in Turkey while this was not the case in Egypt ${ }^{3}$. One of the factors behind the low rate of the litcracy is the low priority given to primary schooling in both countries. Both countries spend significantly larger sums of money to tertiary education than to primary schooling (ADAMS, 2000:260; TANSEL / KAZEMI,1995:14). However, people learn to read and write during basic education. For this reason more public funds need to be allocated to the basic education.

The primary schooling enrollment ratio 4 is higher in Turkey than in Egypt. In Turkey, this ratio is over 100 percent according to World Bank sources, and

3 Unti] 1997 the school system in Turkey included five years of compulsory primary schooling, three years of middle school, three years of high school (four years in the case of vocational high schools) and tertiary levels of schooling. Since 1997 the compulsory level of schooling is extended from five to eight years covering the middle school.

4 Enrollment ratio defined as the enrollment at a school level of children who are of the officially -designated age for that level, expressed as a percentage of the age group population corresponding to that school level. 
illiterate people older than primary school age have been taught in literacy classes and became literate (KEPENEK / YENTÜRK,2000:390-391). In Turkey the primary school enrollment ratio increased from 75 percent (58 percent for females) in the 1960s to 100 percent for both males and females in the 1993. In the following years in Turkey the literacy rate (especially female literacy) and schooling in general will increase further because of the increase in the parental level of education, school availability and industrialization (TANSEL, 2002). Although primary school enrollment ratio is low in Egypt, the secondary school enrollment ratio is fairly high because of the policy of guaranteed public employment policy followed by the government of Egypt for many years (ADAMS, 2000). In both countries enrollment rates in urban areas are higher than those in rural areas.

\section{Income and Poverty}

Income is an important indicator of development. However, by itself, it is not a good measure of welfare. The level of real GNP and its growth rate are important but they do not take into account the distribution of income among the population. Income distribution is an important determinant of the level and structure of poverty (DANSLK, 1997). Therefore, this section will consider the issue of poverty and the next section will address the issue of inequality in income distribution, in order to evaluate the access to resources in Egypt and Turkey.

GDP per capita has increased significantly in both Egypt and Turkey over time. GDP per capita in Egypt was 478 dollars (in 1995 US dollars) in 1970 and increased to 1229 (in 1995 US dollars) in 2001. This represents 3.9 percent annual average increase. GDP per capita in Turkey was 1654 dollars (in 1995 US dollars) in 1970 and increased to 2873 (in 1995 LS dollars) in 2001. This represents 3.5 percent annual average increase. Thus, GDP per capita is higher in Turkey than in Egypt. On the other hand, both countries are classified among lower middle income countries by the World Bank's World Development Report (WDR 2000/2001: 335).

Poverty may be defined as the inability to earn enough income to satisfy the basic human economic and social needs. In general, 40 percent of total households with lowest income are generally accepted as poor. Tables 3 and 4 show the income share of the poorest 40 percent of the households in Egypt and Turkey respectively. Table 3 shows that the income share of the poorest 40 percent of the households has been around 10- 15 percent and did not change much from the mid 1960s to the mid 1990s. The poorest 40 percent received the highest share of about 15 percent in 1987. Table 3 shows the income shares of 
the poorest 40 percent in rural and urban Egypt. The poorest 40 percent of the rural households received the highest shares of around 25 percent in 1981-82 and 1995-96. The poorest 40 percent of the urban households received the highest shares of around 20 percent in 1981-82, 1990-91 and 1995-96. This share declined in 1997 in both rural and urban Egypt indicating an increase in poverty. In general, in Egypt the shares of rural households were larger than that of the urban households. The tables make it clear that the income shares of the poorest 40 percent of the households are larger in Egypt than in Turkey. It is in this sense that poverty in Egypt is lower than in Turkey.

Table 3: Total per Capita Expenditure Accruing to poorest 40\% of Households

\begin{tabular}{lcccccc}
\hline $\begin{array}{l}\text { Egypt } \\
\text { Poorest 40\% of } \\
\text { Households }\end{array}$ & $\mathbf{1 9 6 4}$ & $\mathbf{1 9 7 4}$ & $\mathbf{1 9 8 1 - 8 2}$ & $\mathbf{1 9 9 0 - 9 1}$ & $\mathbf{1 9 9 5 - 9 6}$ & $\mathbf{1 9 9 7}$ \\
Rural & 19 & 17.1 & 24.6 & 19.7 & 25.7 & 17.7 \\
Urban & 16.5 & 18.3 & 21 & 20.3 & 20.4 & 14.8 \\
\hline
\end{tabular}

Source: For 1964-1974 years, B. Hansen, (1991). For 1981-1997 years, R. H. Adams, (2000).

Table 4: Income Accruing to poorest $40 \%$ of households

\begin{tabular}{ccccccc}
\hline Turkey & 1963 & 1968 & 1973 & 1986 & 1987 & 1994 \\
$\begin{array}{c}\text { Poorest } 40 \% \text { of } \\
\text { Households }\end{array}$ & 13 & 10 & 11.5 & 12.3 & 14.85 & 13.5 \\
\hline
\end{tabular}

Source: Income Distribution and Policies, Seventh Anmual Development Plan. Special Expert Commission Repont (in Turkish), SPO, Ankara 1994.

The second approach used in measuring poverty is based on minimum food caloric intake requirements of adults. Using this, poverty line in terms of minimum food expenditure is computed. Households whose income is less than this level are considered poor. Table 5 shows the percent of households whose incomes are below the minimum food expenditure. The table shows a decline in this percent of households in Turkey from 1973 to 1994 indicating a decline in poverty in Turkey over time. Further, poverty is higher in the in the rural than in the urban Turkey. A comparable table does not exist for Egypt. However, Table 6 and 7 show the percent of houscholds below the food and non-food expenditure line in Egypt and Turkey respectively. Table 6 indicates a slight decline in poverty in Egypt and not much difference between urban and rural poverty in 1996 . Further, the percentage of households below the minimum 
food and non- food expenditure lines in Egypt (in 1995-96) and Turkey (in 1994) are about the same. Thus, we can talk about a convergence in poverty in Egypt and Turkey in the mid 1990s.

Table 5: \% of households below minimum food expenditure line in Turkey

\begin{tabular}{lccccc}
\hline Years & $\mathbf{1 9 7 3}^{\mathbf{a}}$ & $\mathbf{1 9 7 8}^{\mathrm{a}}$ & $\mathbf{1 9 8 3}^{\mathbf{a}}$ & $\mathbf{1 9 8 7}^{\mathrm{b}}$ & $\mathbf{1 9 9 4}^{\mathrm{c}}$ \\
\hline Turkey & 32.01 & 24.98 & 29.98 & 15.16 & 11.0 \\
Rural & 49.88 & 42.45 & 51.25 & 21.97 & 14.0 \\
Urban & 12.90 & 8.58 & 12.16 & 9.02 & 7.0 \\
\hline
\end{tabular}

a M.Celasun, (1989), "E. Dansuk. (1997), 'SIS, Labor Market Analysis, (1999).

Source: Columns 1. 2, 3 and 4 from E. Dansuk, (1997). Table 16, p.55. Column 5 from SiS, (1999), Table 5.3. p. 2.5.

Table 6: \% of households below minimum food and non-food expenditure line in Egypt

\begin{tabular}{lccccc}
\hline Egypt & $\mathbf{1 9 6 4}$ & $\mathbf{1 9 7 4}$ & $\mathbf{1 9 8 - 8 2}$ & $\mathbf{1 9 9 0 - 9 1}$ & $\mathbf{1 9 9 5 - 9 6}$ \\
Rural & 24 & 65 & 16.1 & 28.6 & 23.3 \\
Urban & $\mathrm{n} . \mathrm{a}$ & 35 & 18.2 & 20.3 & 22.5 \\
\hline
\end{tabular}

Source: For 1964.1974 years. B. Hansen. (1991). For 1982.1996 vears, R. H. Adams, (2000).

Table 7: \% of households below minimum food and non-food expenditure line in Turkev in 1994

\begin{tabular}{lll}
\hline & \% of households & Poverty Gap Ratio " \\
Turkey & 24.30 & 0.297 \\
Rural & 25.40 & 0.307 \\
Urban & 21.73 & 0.282 \\
\hline
\end{tabular}

Source: SIS, (1999), Table 6.9. p. 39. "Calculated by Sengïl, Seda. (2001).

A third approach to measuring poverty is referred to as the international Standard. In this approach purchasing power parity is used to compute the percent of the population earning below one dollar or two dollars a day. Such people are accepted as internationally poor. Table 8 shows the international 
poverty standards for Egypt and Turkey. This table indicates that 2.4 percent of the population in Turkey (in 1994) was living below one dollar income a day. While the same ratio was 3.1 percent in Egypt (in 1995). The percentage of population living below two dollars income a day was 18 in Turkey and 52 in Egypt. Thus, more than half of the population in Egypt earns less than two dollars a day. This indicates that the extent of poverty in Egypt is much higher than in Turkey by international poverty standards.

Poverty gap is a measure of severity of poverty. As Table 8 makes clear, in Turkey in 1994, poverty gap at one dollar a day was lower than in Egypt in 1990 but higher than in Egypt in 1995. However, both in 1990 and 1995 the poverty gap at two dollars a day were three times higher in Egypt than in Turkey in 1994. This implies that poverty in Egypt is more severe than in Turkey. 5

Table 8: International Poverty Standards

\begin{tabular}{lcccc}
\hline & $\begin{array}{c}\text { \% of } \\
\text { Population } \\
\text { below } \\
\text { \$1 a day }\end{array}$ & $\begin{array}{c}\text { Poverty gap } \\
\text { at } \\
\text { \$1 a day }\end{array}$ & $\begin{array}{c}\text { \% of } \\
\text { Population } \\
\text { below }\end{array}$ & $\begin{array}{c}\text { Poverty gap } \\
\text { at }\end{array}$ \\
\$2 a day \\
Egypt (1990) & 7.6 & 1.1 & 51.9 & 15.3 \\
Egypt (1995) & 3.1 & 0.3 & 52.3 & 11.4 \\
Turkey (1994) & 2.4 & 0.5 & 18 & 5 \\
\hline
\end{tabular}

Source: World Bank, World Development Report 200010I (2000), Table 4. p. 180-181.

\section{Income Inequality}

Gini coefficient is the most commonly used measure of inequality in income distribution. It shows the cumulative proportions of income received by the cumulative proportions of recipients. The Gini coefficient takes values between zero and one. A value of zero means that income distribution is perfectly equal while a value of one means on the contrary, income distribution is perfectly unequal. Table 9 and 10 show the Gini cocfficients for rural and urban Egypt respectively. Table 11 shows the Gini coefficients for Turkey.

5Table 7 also gives the poverty gap ratio for Turkey in 1994. The poverty gap ratio indicates that the required rate of increase in income of the households in Turkey is 29.7 percent ( Seda, 2001). 
We observe that the Gini coefficient in Turkey has been declining over time since 1968 until the late 1980s implying an improvement in income distribution. However, as shown in Table 9, there is an increase in the Gini coefficient since 1987. This indicates that, in the recent years, there is some deterioration in the distribution of income in Turkey. The highly unequal distribution of income in Turkey could be due to recent high rates of unemployment and inflation. Almost a quarter of the total population is below 15 years of age. Unemployment rate of the young is very high. The annual growth rates of the economy have not provided the necessary employment opportunities for its labor force. After the mid-1980s the share of the indirect taxes in the total tax revenues has increased significantly. 'This was one of the factors that contributed to unequal income distribution. Further, it is well known that the tax rates on wage earners in Turkey are one of the highest in Europe. This also contributes to the deterioration in income distribution. There is evidence that income distribution has deteriorated further after the February 2001 crisis. GNP declined by 9.5 percent in 2001 . Real wages and the minimum wage declined by 11.1 and 13.5 percent respectively. The unemployment rate increased from 6.6 percent in 2000 to 9.9 percent in 2001 .

Table 9: Income Distribution in Rural Egypt between 1964 and 1997

\begin{tabular}{lcccccc}
\hline $\begin{array}{l}\text { Expenditure } \\
\text { Groups }\end{array}$ & $\mathbf{1 9 6 4 - 6 5}$ & $\mathbf{1 9 7 4 - 7 5}$ & $\mathbf{1 9 8 1 - 8 2}$ & $\mathbf{1 9 9 0 - 9 1}$ & $\mathbf{1 9 9 5 - 9 6}$ & $\mathbf{1 9 9 7}$ \\
Lowest 20\% & 7.4 & 5.9 & 10.2 & 7.0 & 11.3 & 6.6 \\
Second 20\% & 11.6 & 11.2 & 14.4 & 12.7 & 14.4 & 11.1 \\
Middle 40\% & 38.3 & 37.0 & 40.0 & 37.2 & 39.5 & 36.3 \\
Highest 20\% & 42.7 & 45.9 & 35.4 & 43.1 & 34.8 & 46.0 \\
Gini & 0.29 & 0.35 & 0.275 & 0.36 & 0.235 & 0.321 \\
Coefficient & & & & &
\end{tabular}

Source: For 1964-1975. B. Hunsen. (1991). For 1981-1997. R. H. Adams, (2000). 
Table 10: Income Distribution in Urban Egypt, 1964-1997

\begin{tabular}{lcccccc}
\hline $\begin{array}{l}\text { Expenditure } \\
\text { Groups }\end{array}$ & $\mathbf{1 9 6 4 - 6 5}$ & $\mathbf{1 9 7 4 - 7 5}$ & $\mathbf{1 9 8 1 - 8 2}$ & $\mathbf{1 9 9 0 - 9 1}$ & $\mathbf{1 9 9 5 - 9 6}$ & 1997 \\
Lowest 20\% & $16.5^{\mathrm{a}}$ & $18.3^{\mathrm{a}}$ & 8.4 & 8.2 & 8.4 & 5.4 \\
Second 20\% & - & - & 12.6 & 12.1 & 12.0 & 9.4 \\
$\begin{array}{l}\text { Middle 40\% } \\
\text { Highest }\end{array}$ & $14.8^{\mathrm{h}}$ & $16.1^{\circ}$ & 38.0 & 36.7 & 37.4 & 36.5 \\
$\quad$ 20\% & n.a. & n.a. & 41.0 & 43.0 & 42.2 & 48.7 \\
$\quad \begin{array}{l}\text { Gini } \\
\text { Coefficient }\end{array}$ & $0.40^{\circ}$ & $0.37^{\circ}$ & 0.322 & 0.34 & 0.331 & 0.385 \\
\hline
\end{tabular}

"Sum of the first and the second quintile. "Only third quintile is available. "Taken from the survey done by Hansen (1991). Source: For 1964-1975, B. Hansen, (1991). For 1981-1997, R. H. Adam.s, (2000).

Table 11: Income distribution in Turkey, $1963-1994$

\begin{tabular}{cccccc} 
& $\mathbf{1 9 6 3}^{\mathbf{A}}$ & $\mathbf{1 9 7 3}^{\mathrm{a}}$ & $\mathbf{1 9 8 6}^{\mathrm{b}}$ & $\mathbf{1 9 8 7 ^ { \mathrm { C } }}$ & $\mathbf{1 9 9 4}^{\mathrm{c}}$ \\
$\mathbf{1 . 2 0 \%}$ & 4.5 & 3.5 & 3.9 & 5.2 & 4.9 \\
$\mathbf{2 . 2 0 \%}$ & 8.5 & 8.0 & 8.4 & 9.6 & 8.6 \\
$\mathbf{3 . 2 0 \%}$ & 11.5 & 12.5 & 12.6 & 14.1 & 12.6 \\
$\mathbf{4 . 2 0 \%}$ & 18.5 & 19.5 & 19.2 & 21.2 & 19.0 \\
$\mathbf{5 . 2 0 \%}$ & 57.0 & 56.0 & 55.9 & 49.9 & 54.9 \\
& & & & & \\
Gini Coefficient & 0.55 & 0.51 & 0.50 & 0.43 & 0.49 \\
\hline
\end{tabular}

Source: Han. Ergül (1999). "State Planning Organization. "Turkish Industrial Business Association and State Institute of Statistics.

As Tables 9 and 10 show, the Gini cocfficient in rural and urban Egypt has fluctuated over time. We observe a more equal distribution of income in rural as compared to urban Egypt. Table 11 show's income distribution and Gini coefficients for several years in Turkey. These tables indicate that Turkey's Gini coefficients are higher than those of Egypt implying a higher inequality in income distribution of Turkey than in Egypt. This result is corroborated by the 
percent of households with lowest and highest incomes as shown in Tables 9, 10 and 11 . The tables are based on household surveys. ${ }^{6}$

Table 9 and 10 indicate that in 1964-65, the 20 percent of households with lowest income received 7.4 percent of the total income in rural Egypt and 16.5 percent of the total income in urban Egypt. In 1997, this ratio declined to 6.6 percent in rural Egypt and to 5.4 percent in urban Egypt. The proportion of income received by the 20 percent of households with the highest income increased from about 43 percent in 1964- 65 to 46 percent in 1997 in rural Egypt. The same percentage increased from 41 percent in $1981-82$ to about 49 percent in 1997.

Thus, we can say that income distribution worsened in 1997 in Egypt. The recent poor economic performance was the reason behind this development. During the second half of the 1990s the real GDP growth has declined considerably in Egypt (ADAMS, 2000: 264).

\section{Land and Labor Productivity}

Increasing the returns to factors of production is one of the crucial ways of improving the people's access to food and other resources. Land productivity increases in rural areas and labor productivity increases in urban areas are vital steps in the development process. In this section, productivities of land and labor in Egypt and Turkey will be evaluated and compared to each other and to those of a group of developing countries.

Productivity of land will be evaluated with three related measures. These measures are average annual growth rates in total cereal production, average annual growth rates in irrigation of arable lands and the average annual growth rates in agricultural output per hectare. The Egyptian agriculture is mostly under irrigation. Therefore, the land productivity may not be totally comparable.

Table 12 shows the average annual growth rates in total cereal production for Egypt, Turkey, and seven other developing countries in four periods. During the 1975-1981 period, the growth rate in total cereal production in Turkey is higher than that in Egypt but lower than those in the seven other developing countries. However, after 1987 Egypt's annual growth rates in total

6 However, household surveys in developing countries such as Egypt and Turkey do not yield a reliable picture of income distribution. This is because in many developing countries, the tax evasion as well as the self-employment and unpaid family labor are wide-spread (CELASUN, 1989). 
cereal production far exceeded both of Turkey's and of the other seven developing countries. The reason for the increase in Egypt's cereal production after 1987 is the removal of the governmental marketing and production controls on wheat. "As the profitability of wheat increased, Egyptian farmers responded with ever-increasing wheat yields"(ADAMS, 2000: 270).

Table 12: Average Annual Growth Rates in Total Cereal Production(\%)

\begin{tabular}{ccccc}
\hline & $\mathbf{1 9 7 5 - 8 1}$ & $\mathbf{1 9 8 2 - 8 6}$ & $\mathbf{1 9 8 7 - 9 2}$ & $\mathbf{1 9 9 3 - 9 8}$ \\
Egypt & 0.12 & 1.93 & 9.55 & 3.86 \\
Turkey & 2.30 & 3.59 & 1.53 & 2.48 \\
$\begin{array}{c}7 \text { Developing a } \\
\text { Countries }\end{array}$ & 3.65 & 4.19 & 3.23 & 1.48 \\
\hline
\end{tabular}

a Developing countries are: Argentina. Brazil. Mexico, China, Greece and Iran.

Source: United Nations Food and Agriculture Organization, Production Yearbook (various years).

As land becomes scarce and mechanization increases, irrigation of land becomes important. Table 13 gives information about average annual growth rates in irrigation of arable land in Egypt, Turkey and seven other developing countries. During the entire period of 1970-1997, Egypt had lower (initially negative) growth rates in the irrigation of arable land than Turkey and the seven developing countries.

Table 13: Average Annual Growth Rates in Irrigation of Arable Land (\%)

\begin{tabular}{cccccc} 
& $\mathbf{1 9 7 0 - 7 5}$ & $\mathbf{1 9 7 6 - 8 0}$ & $\mathbf{1 9 8 1 - 8 5}$ & $\mathbf{1 9 8 6 - 9 0}$ & $\mathbf{1 9 9 1 - 9 7}$ \\
\hline Turkey & 2.0 & 1.12 & 0.97 & 15.96 & 1.72 \\
Egypt & -0.15 & -3.35 & 0.40 & 1.35 & 4.33 \\
$\begin{array}{c}\text { 7 Developing } \\
\text { Countries }^{2}\end{array}$ & 4.48 & 2.62 & 2.32 & 2.90 & 2.08 \\
\hline
\end{tabular}

7 Developing countries are: Argentina, Brazil, Mexico, China, Greece and Iran.

Source: United Nations Food and Agriculture Organization, Production Yearbook (various years).

During 1986-1990 period, irrigation of arable land in Turkey annually grew, on average, by 15.96 percent, which is a great achievement. Southeast Anatolian Project in the South East of Turkey started irrigation during this 
period. However, during the 1991-97 period the growth rate of irrigation was higher in Egypt than in Turkey and seven other developing countries.

In Table 14, average annual growth rates in agricultural output per hectare are shown for Egypt, Turkey and seven other developing countries. After 1980, the annual growth rates in agricultural output per hectare have continuously decreased in Turkey. During the 1975-80, the growth rate of the agricultural output per hectare was highest in Turkey. During 1992-98 the growth rate of the agricultural output per hectare was higher in Egypt than in Turkey and seven other developing countries.

Table 14: Average Annual Growth Rates in Agricultural Output per Hectare \%

\begin{tabular}{lccccc}
\hline & $\mathbf{1 9 6 9 - 7 4}$ & $\mathbf{1 9 7 5 - 8 0}$ & $\mathbf{1 9 8 0 - 8 5}$ & $\mathbf{1 9 8 6 - 9 1}$ & $\mathbf{1 9 9 2 - 9 8}$ \\
Egypt & 0.6 & 2.55 & -0.04 & 0.38 & 2.90 \\
Turkey & 3.57 & 5.17 & 0.31 & 0.06 & 0.05 \\
7 Developing & 3.62 & 3.96 & 0.87 & 1.05 & 1.88 \\
Countries " & & & & & \\
\hline
\end{tabular}

a 7 Other Developing Countries: Argentina, Brazil, Mexico, China, India, Greece and Iran. Source: United Nations Food and Agriculture Organization. Production Yearbooklvarious years).

Table 15: Average Annual Growth Rate of Labor Productivity (\%)

\begin{tabular}{cccc}
\hline Egypt & $\mathbf{1 9 6 0 - 7 0}$ & $\mathbf{1 9 7 0 - 7 7}$ & $\mathbf{1 9 8 0 - 9 0}$ \\
$\begin{array}{c}\text { Industrial Value } \\
\text { Added }\end{array}$ & 5.4 & 7.2 & 5.2 \\
$\begin{array}{c}\text { Industrial } \\
\text { Employment }\end{array}$ & h \\
$\begin{array}{c}\text { Labor } \\
\text { productivity in } \\
\text { Industry }^{\text {c }}\end{array}$ & 3.9 & 4.2 & 2.7 \\
\hline
\end{tabular}

Source: "For the 1960-77 years, World Bank, World Development Report, 1980, p. 112. For the 1980- 2000 years, , World Bank, World Development Report, 2000/2001, p.294. " For the 1960 70 years, International Labor Organization (ILO), Yearbook of Statistics, (1945-89), p.134, (1981). p.194; for 1970-77 years International Labor Organization (ILO), Yearbook of Statistics, (1986). p. 309. "This row is computed by the author. 
Table 16. Average Annual Growth Rate of Labor Productivity (\%)

\begin{tabular}{ccccc}
\hline $\begin{array}{c}\text { Turkey } \\
\text { Industrial }\end{array}$ & $\mathbf{1 9 6 0 - 7 0}$ & $\mathbf{1 9 7 0 - 7 7}$ & $\mathbf{1 9 8 0 - 9 0}$ & $\mathbf{1 9 9 0 - 2 0 0 0}$ \\
$\begin{array}{c}\text { value added } \\
\text { Industrial }\end{array}$ & 9.6 & 8.8 & 7.8 & 4.8 \\
$\begin{array}{c}\text { Employment } \\
\begin{array}{c}\text { Labor } \\
\text { Productivity } \\
\text { in industry }\end{array}\end{array}$ & 3.85 & 2.6 & 4.8 & 4.4 \\
\hline
\end{tabular}

Source: "For the 1960-77 years. World Bank, World Development Report, 1980, p. 112. For the 1980. 2000 years, World Bank, World Development Report, 2000/2001, p.294. ${ }^{b}$ For the 1960-1970 and 1970-1977. OECD, Labor Force Statistics, 1985, p.426; 1992, p.436. For the 1980-1990 and 1990-2000, SPO. Main Economic Indicators, 1989, p.87; 1995, p.133. " This row is computed by the author.

Table 15 and 16 show the changes in the average annual growth rate in labor productivity in Egypt and in Turkey respectively from 1960 to 1990. Average annual growth rate of industrial value added in Egypt is lower than in Turkey in all three decades. Labor productivity growth rate declined considerably over time in Turkey from 5.75 percent in 1960-1970 to 0.4 percent in 1990-2000. In Egypt it first increased from 1960-70 to 1970-77 then declined in 1980-90. The relatively low level of productivity in both Egypt and Turkey can be attributed to the slow progress in privatization.

Table 16 show's the changes in the average annual growth rate in labor productivity in Turkey from 1960 to 2000 . As can be seen from the table, average annual growth rate of industrial value added in Turkey has decreased over the years. On the other hand, industrial employment has increased slightly from the beginning of the 1960s to the end of the 1990s. In that sense, average annual growth rate of labor productivity in the industrial sector for Turkey decreased from 5.75 percent in the 1960s to 0.4 percent in the 1990s.

\section{Summary and Conclusions}

This article evaluated and compared the development records of Egypt and Turkey. Five indicators of development are used in this process. These are life expectancy at birth, adult literacy rate, income and poverty, inequality in income distribution and finally, land and labor productivity.

Both Egypt and Turkey experienced significant improvements in life expectancy at birth since the 1960s. During the period 1960 to 1997, the 
average rate of improvement in life expectancy in Egypt exceeded that of Turkey. However, in 1997, the life expectancy at birth in Egypt is considerably below that in Turkey. Over time, Turkey has shown faster improvements in the adult literacy rate than Egypt. This is due to the law of compulsory primary schooling in Turkey since the early years of the Republic of Turkey. As a result, the current adult literacy rate in Turkey is much higher than that in Egypt.

In terms of poverty, one of the measures considered is the income share of the poorest households. This share has been lower in Turkey than in Egypt during the period of 1963-1997 indicating that the poverty in Turkey has been higher than that in Egypt. Further, while the income share of the poorest 40 percent of the households has remained more or less constant in Turkey, this share has increased considerably in Egypt over the period 1964-1995. However, there was a drop in this share in 1997 in Egypt. This indicates that while poverty level did not change much in Turkey, there were significant improvements in poverty in Egypt since the 1960s. As a second measure of poverty the percent of households below the minimum food and non-food expenditure line is used. In the 1990s the percent of households below the minimum food and non-food expenditure line was about the same in Egypt and Turkey. In both countries, in terms of this measure the rural poverty was found to be higher than the urban poverty. The third measure of poverty used was the population below one or two dollars a day. In the 1990s the percent of population below one dollar a day was about the same in Egypt and Turkey. However, the percent of population below two dollars a day was about three times more in Egypt than in Turkey.

Next, the inequality in income distribution is considered. In order to assess the inequality in income distribution one of the measures used was the Gini coefficient. The Gini coefficient in Turkey has shown a declining trend, indicating improvements in income distribution since the 1960s. The Gini coefficient in Egypt has fluctuated over time since the 1960s, indicating improvements in income distribution in some years and worsening in income distribution in other years. However, as shown in the Tables 10 and 11, calculated Gini coefficients for all the time periods indicate that the Gini coefficient in Turkey is much higher than that in Egypt. Therefore, income distribution is more unequal in Turkey than that in Egypt.

In order to evaluate the productivity of land, three measures are used. These measures are average annual growth rate in cereal production, average annual growth rate in irrigation of arable land and average annual growth rate in agricultural output per hectare. Average annual growth rate in cereal production in the 1990 was higher in Egypt than in Turkey and seven other developing 
countries. Again in the 1990 s the average annual growth rate in irrigation of arable land was higher in Egypt than in Turkey and in the seven other developing countries. However, Turkey experienced the highest average annual growth rate in this respect during the second half of the 1980s. In the 1990s average annual growth rate in agricultural output per hectare was higher in Egypt than in Turkey and seven other developing countries. Thus, we can conclude that, recently, the productivity of land was higher in Egypt than in Turkey and in the seven other developing counties by the three measures considered. The last concept considered was the labor productivity. Due to data limitations, labor productivity was considered only in the industry. In Turkey the average annual growth rate of labor productivity in industry declined considerably over time since the 1960s while it increased considerably in Egypt over the same period.

In conclusion we can say that while Turkey is ahead of Egypt in terms of some development indicators such as the life expectancy at birth and the literacy rate, Turkey is behind Egypt in term of other development indicators. Inequality in the distribution of income is higher in Turkey than in Egypt. Poverty may be considered to be about the same in two countries depending on the measure used. Further, recently, the productivity of land and labor are both higher in Egypt than in Turkey. Higher productivity of land and labor in Egypt may imply better prospects of development for Egypt than in Turkey. However, Egypt needs to focus on improving investment in human capital.

\section{Refences}

ADAMS, Richard H. (2000), "Evaluating the Process of Development in Egypt, 1980-97," International Journal of Middle Eost Studies, 32: 255-275.

CELASUN, Merih (1989), "Income Distribution and Employment Aspects of Turkey's Post- 1980 Adjustment," METU Studies in Development, 16/3-4: 1-31.

DANSUK, Ercan (1997), "Measurement of Poverty in Turkey and Its Relation to Socio- economical Structures," (in Turkish) (Ankara: SPO).

ESMER, Y. / FIŞEK, H. / KALAYCIOĞLU, E. (1986), Research Series on Social and Economic Priorities Vol. 2, (in Turkish) (istanbul: TÜSiAD).

HADDAD, W. D. [et al] (1990), Educotion and Development: Evidence for New Priorities, No. 95 (Washington, D.C.: World Bank Discussion Paper).

HAN, Ergül (1999), Income Distribution in Turkey (in Turkish), ÖZER, Mustafa (Ed.) (Açıöogretim Fakültesi Yayınlan No.608).

HANSEN, B. (1992), The political Economy of Poverty, Equity and Growth: Egypt and Turkey (New York: Oxford University Press).

KEPENEK Y. / YENTÜRK N. (2000), Turkish Economy (in Turkish) (11 ${ }^{\text {in }}$ Edition): 390-391.

SUBBARAO, K. / RANEY, L. (1995), "Social Gains from Female Education: A Cross-National Study," Economic Development and Cultural Change, 44/1 (October ): 105-16.

TANSEL, Aysit (2002), "Determinants of School Attainment of Boys and Girls in Turkey: Individual, Household and Community Factors," Economics of Education Review, 21: 455-470. 
TANSEL, A. / KAZEMI, A. (2000) "Educational Expenditures in the Middle East and North Africa," Middle Eastern Studies, 36/4: 75-98.

Tilak, Jandhyala B. G. (1989), Education and its Relation to Economic Growth, Poverty, and Income Distribution (Washington, D.C.: World Bank Discussion Papers): 24.

ŞENGÜL, Seda (2001), Poverty Profile and Food Demand According to Income Groups in Turkey (in Turkish) (Adana: Unpublished Ph.D. thesis, Cukurova Üniversitesi).

STATE PLANING ORGANIZATION (SPO) (1976), Research on Income Distribution (in Turkish) (Ankara.: SPO).

STATE PLANING ORGANIZATION (SPO), (1994), "Income Distribution and Policies," Seventh Annual Development Plan, Special Expert Commission Report (in Turkish) (Ankara: SPO, Table: 63,84).

STATE INSTITUTE OF STATISTICS (SIS) (1990), Income Distribution in 1987 (in Turkish) (Ankara).

UNDP, Human Development Report (1990), Oxford University Press.

UNDP, Human Development Report (1998), Oxford University Press.

THE WORLD BANK, Development Report (1990), Washington, D.C.

THE WORLD BANK, Development Report (1998), Washington, D.C.

THE WORLD BANK, Development Report (2000/2001), Washington, D.C.

THE WORLD BANK, Development Report ( 2002), Washington, D.C.

THE WORLD BANK, Development Report (1998-1999), Washington, D.C. 